\title{
DAMPAK FILM TELEVISI TERHADAP PERILAKU SISWA
}

\section{Abstrak}

Tujuan penelitian ini adalah untuk mengetahui apakah terdapat perbedaan persepsi pengawas sekolah terhadap dampak film dalam televisi terhadap perilaku siswa. Berdasarkan analisis Chi-Square dari 98 responden pengawas sekolah di 15 provinsi, yang terdiri dari (1) pengawas sekolah TK/SD/SDLB, (2) pengawas sekolah rumpun mata pelajaran (RM), dan (3) pengawas sekolah bimbingan dan konseling (BK), maka diperoleh hasil penelitian seperti berikut ini. Hasil penelitian yang pertama menunjukkan bahwa menonton televisi dalam hari-hari sekolah dapat mengganggu belajar siswa. Alasannya di antaranya adalah karena: anak akan lupa belajar jika acaranya menarik, konsentrasi belajar siswa tidak terfokus, acaranya tidak sesuai dengan mata pelajaran, siswa menjadi malas belajar. Hasil penelitian ini, termasuk hasil penelitian berikut, menunjukkan tidak terdapat perbedaan di antara para pengawas sekolah $(P>0,05)$. Hasil penelitian berikutnya menunjukkan bahwa: (1) iklan yang ditonton/ ditayangkan di televisi dapat berdampak negatif terhadap perilaku siswa, (2) film komedi berdampak positif terhadap perilaku siswa, (3) film drama keluarga berdampak positif terhadap perilaku siswa, (4) film horor/setan yang ditayangkan di televisi dapat berdampak negatifterhadap perilaku siswa, (5) film kartun berdampak positif terhadap perilaku siswa, dan (6) film keagamaan berdampak positif terhadap perilaku siswa.

*) Drs. Safari, M.A. adalah peneliti pendidikan pada Pusat Penilaian Pendidikan, Balitbang Depdiknas, Jakarta. 


\section{A. LATAR BELAKANG DAN MASALAH}

Mudah-mudahan tahun ini aman dan damai, tidak terjadi apa-apa setelah nilai Ujian Akhir Nasional (UAN) diumumkan. Semoga para siswa diberi ketenangan dan kesejukan dalam mendaftar dan mengikuti tes pada penerimaan murid baru untuk jenjang yang lebih tinggi. Selamat kepada para siswa yang lulus dan diterima di sekolah berikutnya. Kepada siswa yang "belum lulus" bersabarlah, berdoa, dan belajarlah yang optimal, serta berbaktilah kepada kedua orangtua, semoga Anda lulus pada ujian ulangan pada bulan Juli 2004 nanti dan dapat melanjutkan ke jenjang berikutnya, amin.

Setiap ada ujian akhir sekolah kita diingatkan dengan beberapa peristiwa yang mengerikan. Misalnya kita masih ingat peristiwa tahun lalu, yaitu puluhan pelajar sekolah lanjutan tingkat atas (SLTA) membajak tiga bus kota, yaitu P4 jurusan Pulo Gadung-Blok M, PAC jurusan Pulo Gadung-Grogol, dan bus reguler 64 jurusan Pulo Gadung-Kalideres pada hari Jumat siang 9-5-2003. Perbuatan kriminal ini dilakukan para pelajar yang baru saja mengikuti ujian akhir sekolah. Saat melakukan kejahatan itu mereka juga masih mengenakan seragam sekolah (Kompas, Sabtu, 10 Mei 2003, halaman 18). Peristiwa yang lain, antara bulan Januari hingga pertengahan Mei 2003, penyalahgunaan narkotika dan obat-obatan berbahaya (narkoba) oleh para pelajar terus meningkat. Pelajar yang ditangkap aparat Kepolisian Resor Metro Jakarta Utara karena menggunakan narkoba dalam lima bulan terakhir terus meningkat yaitu berjumlah 30 siswa SD, 27 siswa SLTP dan 55 pelajar SLTA (Kompas, Selasa, 13 Mei 2003, halaman 18).

Kejadian seperti itu sangat memprihatinkan. Seharusnya para siswa itu memberi contoh yang baik kepada masyarakat. Apa yang sedang terjadi pada diri siswa itu? Mengapa mereka bertingkah laku agresif seperti itu? Apakah mereka sedang memerankan tokoh utama dari film yang mereka tonton di televisi? Apakah mereka merasa kecewa dengan ujian yang baru saja mereka kerjakan? Mengapa orang lain yang menjadi sasarannya? Apa yang salah dalam proses 
belajar-mengajar di sekolah mereka? Apakah pengawas sekolah belum memberikan pembinaan sekolahnya secara maksimal? Masih banyak sederet pertanyaan yang dapat disampaikan sehubungan dengan perilaku agresif para pelajar itu.

Saat ini masyarakat sudah mulai mengerti bahwa belajar bukan hanya sekedar membaca melainkan di dalamnya termasuk adanya proses perubahan perilaku (Skinner dalam Bell-Gredler, 1986). Pernyataan ini dikuatkan Cronbach (1963). Beliau menyatakan bahwa belajar ditunjukkan oleh sebuah perubahan pada perilaku seperti suatu hasil pengalaman. Pendapat Cronbach dikuatkan BellGredler (1986) yang menyatakan bahwa belajar merupakan proses manusia dalam memperoleh macam-macam kemampuan, keterampilan, dan sikap. Di samping itu, Robert Gagne dalam BellGredler (1986) juga mengategorikan bahwa belajar meliputi: informasi verbal, keterampilan intelektual, strategi kognitif, keterampilan motorik, dan sikap.

Untuk mendukung adanya perubahan perilaku, maka selanjutnya Cronbach membagi 7 konsep utama terhadap proses belajar, yaitu dalam belajar harus memperhatikan: situasi (meliputi objek, orang, dan simbol-simbol keperluan orang yang belajar), ciri-ciri personal (meliputi kemampuan dan respon), tujuan, interpretasi, tindakan (action), akibat (harapan orang), dan reaksi terhadap hambatan.

Guna mendukung pelaksanaan belajar siswa, apakah para guru, para orangtua murid telah mempersiapkannya sejak dini mulai dari awal siswa menerima materi pelajaran di sekolah? Pola yang dipersiapkan sejak dini sangat penting karena dapat mendukung pengembangan kognitif siswa yang meliputi 3 periode, yaitu : kegiatan sensorimotor, awal operasional berpikir, dan operasional berpikir (Sutherland, 1992). Munandar (1990) juga menyatakan bahwa belajar kreatif tidak timbul secara kebetulan tetapi memerlukan persiapan. Persiapan yang dimaksud menurut Feldhusen dan Treffinger dalam Munandar (1990) di antaranya 
menciptakan lingkungan kreatif, yaitu dengan cara: memberikan pemanasan, pengaturan fisik, kesibukan di dalam kelas, dan guru sebagai fasilitator.

Dalam menciptakan lingkungan kreatif, siswa perlu dibimbing melalui perlakuan-perlakuan kreatif yang positif karena apabila sebaliknya yaitu sering menerima perlakuan kekerasan, maka anakanak pun bisa melimpahkan kekerasan kepada orang lain (Baihaqi, 1998) dan bertingkah laku agresif. Tingkah laku agresif dapat dibagi dua yaitu agresi permusuhan (hostile aggression) dan agresi instrumental (instrumental aggression) (Myers, 1993: 421). Agresi permusuhan merupakan tingkah laku yang berindikasi pernyerangan, penyiksaan, serta gangguan. Agresi instrumental merupakan hasil dari suatu kompetisi untuk meraih sesuatu yang berharga dalam kehidupan sehari-hari. Tawuran siswa merupakan sebagian dari perilaku agresif permusuhan dalam bentuk perkelahian masal antarsiswa yang mempunyai makna perbuatan bermusuhan, berifat penyerangan fisik ataupun psikis terhadap siswa lain (Reven and Rubin, 1983: 267).

Faktor yang merangsang perilaku agresif tawuran antara lain: (1) perubahan lingkungan, (2) pemakaian alkohol dan bahan kimia psikotropika seperti narkoba, (3) rasa frustasi, (4) meniru model perilaku agresif pada film, TV, dan media masa, (5) kekerasan institusional (Aromson, Wilson, and Akert, 1994: 490-491). Tawuran siswa bertujuan melukai atau merusak tindakannya dalam bentuk menampar, menjatuhkan, membanting, menghina, merusak, yang dapat dilakukan dengan tenang atau dalam ledakan emosional (Myers, 1994: 244). Acara atau program yang disajikan stasiun televisi juga menggiurkan siswa khususnya pada saat siswa sedang belajar. Saat ini terdapat 11 stasiun televisi, yaitu: TVRI, TPI, RCTI, SCTV, ANTV, INDOSIAR, METROTV, TRANSTV, GLOBAL TV, TV7, dan LATIVI. Setiap setasiun TV selalu berkompetisi dalam rangka mencari atau merebut pemirsa. 
Berdasarkan uraian di atas, maka permasalahan yang muncul adalah seperti berikut ini. Apakah terdapat perbedaan persepsi pengawas, yaitu (1) pengawas sekolah TK/SD/SDLB, (2) pengawas sekolah rumpun mata pelajaran (RM), dan (3) pengawas sekolah bimbingan dan konseling (BK), terhadap dampak menonton televisi dalam hari-hari sekolah pada perilaku siswa? Apakah terdapat perbedaan persepsi pengawas sekolah terhadap dampak program tayangan dalam TV seperti: iklan, film komedi, film drama keluarga, film horor/setan, film kartun, film keagamaan pada perilaku siswa? Oleh karena itu hipotesis penelitian ini yang diajukan adalah adanya perbedaan persepsi pengawas sekolah terhadap: (1) dampak menonton televisi dalam hari-hari sekolah, (2) dampak tingkah laku siswa pada program tayangan dalam TV seperti: iklan, film komedi, film drama keluarga, film horor/setan, film kartun, film keagamaan.

\section{B. METODE PENELITIAN}

Subjek penelitian ini adalah para pengawas sekolah di 15 propinsi yang pernah mengikuti training of trainer (TOT) pendidikan dan pelatihan fungsional calon pengawas sekolah yang diselenggarakan Direktorat Tenaga Kependidikan, Direktorat Jenderal Pendidikan Dasar dan Menengah pada tanggal 16-23 Juli 2001di Balai Penataran Guru, Jalan Kiyai Mojo, Srondol Barat, Semarang, Jawa Tengah. Pengawas sekolah yang menjadi responden adalah pengawas sekolah TK/SD/SDLB, pengawas sekolah rumpun mata pelajaran (RM), pengawas sekolah bimbingan dan konseling (BK).

Berdasarkan kuesioner yang masuk dan desain penelitian ini, maka ditetapkan bahwa sampel penelitian ini adalah 98 responden. Penentuan pengawas sekolah ini dipilih secara random sehingga jumlahnya adalah seperti berikut. Di Propinsi: DI Aceh = 1 pengawas, Sumatera Utara $=2$ pengawas, Riau $=2$ pengawas, Sumatera Barat $=2$ pengawas, Jambi $=5$ pengawas, Sumatera Selatan $=6$ pengawas, Lampung $=3$ pengawas, Bengkulu $=4$ pengawas, $\mathrm{DKI}$ Jakarta $=6$ pengawas, Jawa Barat $=17$ pengawas, Jawa Tengah $=$ 10 pengawas, $\mathrm{DI}$ Yogyakarta $=2$ pengawas, Jawa Timur $=32$ 
pengawas, Banten $=5$ pengawas, Bangka Belitung $=1$ pengawas .

Responden perempuan berjumlah 11 orang yang terdiri dari pengawas $\mathrm{TK} / \mathrm{SD} / \mathrm{SLB}=5$ orang, pengawas $\mathrm{MP}=6$ dan responden laki-laki berjumlah 87 orang yang terdiri dari pengawas TK/SD/SLB $=17$ orang, pengawas $\mathrm{MP}=56$ orang, pengawas $\mathrm{BK}=14$ orang. Secara rata-rata usia responden adalah 34 tahun, usia minimal 34 tahun dan usia maksimal 58 tahun. Jumlah sekolah yang menjadi tanggung jawabnya secara rata-rata berjumlah 22 sekolah, minimumnya 5 sekolah dan maksimumnya 74 sekolah. Latar belakang pendidikan responden untuk $\mathrm{S}-2=14$ orang, $\mathrm{S}-1=77$ orang, sarjana muda $=2$ orang, D-3 $=1$ orang, D-2 $=4$ orang.

Instrumen yang dipergunakan dalam penelitian ini adalah kuesioner. Kuesioner yang diberikan kepada responden berisi identitas subjek dan butir-butir pertanyaan yang berhubungan dengan persepsi subjek terhadap permasalahan dalam penelitian ini. Semua variabel dalam penelitian ini merupakan variabel independen yang meliputi variabel: (1) dampak menonton televisi dalam hari-hari sekolah, (2) dampak program tayangan dalam TV seperti: iklan, film komedi, film drama keluarga, film horor/setan, film kartun, film keagamaan terhadap perilaku siswa.

Karena data dalam penelitian ini berbentuk deskrit atau berskala nominal, maka metode analisis yang dipergunakan untuk menjawab tujuan penelitian ini adalah Chi-Square yaitu mempergunakan Pearson dan Likelihood Ratio Chi-Square. Agar hasil analisis penelitian ini dapat diperoleh secara akurat, maka semua data dalam penelitian ini diolah atau dianalisis dengan mempergunakan program SPSS for Window Release 6,0 (Norusis, 1993). 


\section{HASIL PENELITIAN DAN PEMBAHASAN}

\section{Menonton televisi dalam hari-hari sekolah}

Berdasarkan analisis dari 98 pengawas sekolah menunjukkan bahwa $64(65,3 \%)$ responden menyatakan bahwa menonton televisi dalam hari-hari sekolah mengganggu belajar siswa dan hanya $34(34,7 \%)$ responden yang menyatakan bahwa menonton televisi dalam hari-hari sekolah tidak mengganggu belajar siswa.

Berdasarkan Tabel 1 menunjukkan bahwa adanya perbedaan persepsi pengawas sekolah terhadap dampak menonton televisi dalam hari-hari sekolah adalah tidak terbukti $(P>0,05)$. Ini menunjukkan bahwa hipotesis nol penelitian ini diterima, yaitu tidak terdapat perbedaan persepsi pengawas terhadap dampak menonton televisi dalam hari-hari sekolah. Artinya bahwa sebagian besar $(65,3 \%)$ pengawas sekolah menyatakan bahwa menonton televisi dalam hari-hari sekolah mengganggu belajar siswa.

\section{Tabel 1.}

Hasil Chi-Square tentang persepsi pengawas sekolah terhadap dampak menonton televisi dalam hari-hari sekolah

\begin{tabular}{cccc}
\hline \hline Chi-Square & Value & DF & Significance \\
\hline Pearson & 3,643 & 2 & 0,162 \\
Likelihood Ratio & 3,468 & 2 & 0,177 \\
\hline \hline
\end{tabular}

Alasan responden yang menyatakan bahwa menonton televisi dalam hari-hari sekolah mengganggu belajar siswa di antaranya adalah karena: (1) dapat lupa belajar jika acaranya menarik, (2) konsentrasi belajar siswa tidak terfokus, (3) acaranya tidak sesuai dengan mata pelajaran, (4) siswa menjadi malas belajar, (5) waktunya tidak teratur, (6) belum semua siswa menyadari, (7) siswa mudah terpengaruh dengan tokoh tertentu. Adapun 
alasan responden yang menyatakan bahwa menonton televisi dalam hari-hari sekolah tidak mengganggu belajar siswa di antaranya adalah karena: (1) siswa perlu hiburan asal tahu waktu dan tidak mengganggu waktu belajar, (2) ada tayangan televisi yang memuat ilmu pengetahuan, (3) siswa dapat mengatur konsentrasi belajarnya, (4) untuk menambah wawasan siswa.

\section{Iklan}

Berdasarkan analisis dari 98 pengawas sekolah menunjukkan bahwa rata-rata responden yang menyatakan bahwa iklan berdampak negatif terhadap perilaku siswa adalah $64 \%$ responden dan yang menyatakan berdampak positif terhadap perilaku siswa adalah $36 \%$. Keterangan lebih lengkap dapat dilihat pada Tabel 2 berikut.

\section{Tabel 2.}

Rata-rata, standardeviasi, minimal, dan maksimal persentase persepsi pengawas sekolah terhadap dampak iklan yang ditayangkan televisi pada tingkah laku siswa

\begin{tabular}{lcccc}
\hline \hline Dampak & Rata-rata & Standardeviasi & minimum & maksimum \\
\hline Positif & $35,62 \%$ & 19,78 & $1 \%$ & $90 \%$ \\
Negatif & $64,48 \%$ & 19,94 & $10 \%$ & $100 \%$ \\
\hline
\end{tabular}

Berdasarkan Tabel 3 menunjukkan bahwa adanya perbedaan persepsi pengawas sekolah terhadap dampak iklan yang ditayangkan televisi pada tingkah laku siswa adalah tidak terbukti ( $P>0,05)$. Ini menunjukkan bahwa hipotesis nol penelitian ini diterima, yaitu tidak terdapat perbedaan persepsi pengawas terhadap dampak iklan yang ditayangkan televisi pada tingkah laku siswa. Artinya bahwa sebagian besar $(64,48 \%)$ pengawas sekolah menyatakan bahwa iklan yang 
ditayangkan di televisi berdampak negatif terhadap tingkah laku siswa.

Tabel 3.

Hasil Chi-Square tentang persepsi pengawas sekolah terhadap dampak iklan yang ditayangkan televisi pada tingkah laku siswa

\begin{tabular}{llcc}
\hline \hline Dampak & Pearson & df & Significance \\
\hline Positif & 39,350 & 32 & 0,174 \\
Negatif & 39,569 & 32 & 0,235 \\
\hline \hline
\end{tabular}

Contoh dampak positif siswa dalam menonton iklan yang disampaikan responden di antaranya adalah: (1) mengetahui produksi dalam negeri, (2) mengetahui kesehatan, (3) dapat menambah pengetahuan, (4) mencintai produksi dalam negeri, (5) mengetahui barang baru, (6) mengetahui barang yang berguna, (7) mengikuti teknologi, (8) meniru lagu-lagunya, (9) anak bergembira, (10) mengetahui lingkungan hidup. Contoh dampak negatif siswa dalam menonton iklan yang disampaikan responden di antaranya adalah: (1) siswa ingin mencoba, (2) meniru gerakan yang diperagakan, (3) ingin memiliki semua yang diiklankan, (4) mencontoh yang tidak baik, (5) tidak semua produk sesuai dengan kondisi siswa, (6) membawa siswa ke dunia serba ada, (7) merasa tuntutan tidak terpenuhi, (8) menirukan kekerasan, (9) selera tidak realistis, (10) siswa sulit membedakan antara perbuatan yang baik dan buruk.

\section{Film komedi}

Berdasarkan analisis dari 98 pengawas sekolah menunjukkan bahwa rata-rata responden yang menyatakan bahwa film komedi berdampak positif terhadap perilaku siswa adalah 54\% responden dan yang menyatakan berdampak negatif terhadap 
perilaku siswa adalah $46 \%$. Keterangan lebih lengkap dapat dilihat pada Tabel 4 berikut.

Tabel 4.

Rata-rata, standardeviasi, minimal, dan maksimal persentase persepsi pengawas sekolah terhadap dampak film komedi pada tingkah laku siswa

\begin{tabular}{lrccc}
\hline \hline Dampak & Rata-rata & Standardeviasi & minimum & maksimum \\
\hline Positif & $54 \%$ & $22,17 \%$ & $2 \%$ & $100 \%$ \\
Negatif & $46 \%$ & $22,17 \%$ & $0 \%$ & $98 \%$ \\
\hline
\end{tabular}

Berdasarkan Tabel 5 menunjukkan bahwa adanya perbedaan persepsi pengawas sekolah terhadap dampak film komedi yang ditayangkan televisi pada tingkah laku siswa adalah tidak terbukti $(P>0,05)$. Ini menunjukkan bahwa hipotesis nol penelitian ini diterima, yaitu tidak terdapat perbedaan persepsi pengawas sekolah terhadap dampak film komedi yang ditayangkan televisi pada tingkah laku siswa. Artinya bahwa sebagian besar $(54 \%)$ pengawas sekolah menyatakan bahwa film komedi yang ditayangkan di televisi berdampak positif terhadap tingkah laku siswa.

Tabel 5.

Hasil Chi-Square tentang persepsi pengawas sekolah terhadap dampak film komedi yang ditayangkan televisi pada tingkah laku siswa

\begin{tabular}{llcc}
\hline \hline Dampak & Pearson & df & Significance \\
\hline Positif & 27,378 & 28 & 0,498
\end{tabular}


Contoh dampak positif siswa dalam menonton film komedi yang disampaikan responden di antaranya adalah: (1) menghibur, (2) belajar humor, (3) menambah wawasan, (4) memahami isi cerita, (5) mengurangi stres/refresing, (6) meniru perilaku yang baik. Contoh dampak negatif siswa dalam menonton film komedi yang disampaikan responden di antaranya adalah: (1) banyak komedi yang kurang mendidik, (2) dapat meniru peran yang jelek, (3) anak menjadi kurang/tidak serius, (4) mengganggu orang lain, (5) anak sering membuat sensasi, dibuat-buat, suka iseng, banyak bercanda, (6) tidak bisa membedakan antara serius dan bercanda.

\section{Film drama keluarga}

Berdasarkan analisis dari 98 pengawas sekolah menunjukkan bahwa rata-rata responden yang menyatakan bahwa film drama keluarga berdampak positif terhadap perilaku siswa adalah $53,48 \%$ responden dan yang menyatakan berdampak negatif terhadap perilaku siswa adalah 46,52\%. Keterangan lebih lengkap dapat dilihat pada Tabel 6 berikut.

\section{Tabel 6.}

Rata-rata, standardeviasi, minimal, dan maksimal persentase persepsi pengawas sekolah terhadap dampak film drama keluarga pada tingkah laku siswa

\begin{tabular}{lcccc}
\hline \hline Dampak & Rata-rata & Standardeviasi & minimum & maksimum \\
\hline Positif & $53,48 \%$ & $22 \%$ & $0 \%$ & $95 \%$ \\
Negatif & $46,52 \%$ & $22 \%$ & $5 \%$ & $100 \%$ \\
\hline
\end{tabular}

Berdasarkan Tabel 7 menunjukkan bahwa adanya perbedaan persepsi pengawas sekolah terhadap dampak film drama 
keluarga yang ditayangkan televisi pada tingkah laku siswa adalah tidak terbukti $(P>0,05)$. Ini menunjukkan bahwa hipotesis nol penelitian ini diterima, yaitu tidak terdapat perbedaan persepsi pengawas terhadap dampak film drama keluarga yang ditayangkan televisi pada tingkah laku siswa. Artinya bahwa sebagian besar $(53 \%)$ pengawas sekolah menyatakan bahwa film drama keluarga yang ditayangkan di televisi berdampak positif terhadap tingkah laku siswa.

\section{Tabel 7.}

Hasil Chi-Square tentang persepsi pengawas sekolah terhadap dampak film drama keluarga yang ditayangkan televisi pada tingkah laku siswa

\begin{tabular}{lccc}
\hline \hline Dampak & Pearson & df & Significance \\
\hline Positif & 36,769 & 34 & 0,342 \\
Negatif & 36,769 & 34 & 0,342 \\
\hline \hline
\end{tabular}

Contoh dampak positif siswa dalam menonton film drama keluarga yang disampaikan responden di antaranya adalah: (1) menghargai orangtua, (2) memanfaatkan pesan baik, (3)menenal keluarga, (4) lebih mengenal kehidupan, (5) menyelesaikan masalah keluarga, (6) simpatik pada tokoh, (7) mencari idola, (8) kasih sayang, (9) membina sikap, (10) belajar memecahkan masalah. Contoh dampak negatif siswa dalam menonton film drama keluarga yang disampaikan responden di antaranya adalah: (1) sering menampilkan kekerasan, (2) menimbulkan contoh yang tidak baik, (3) membuat siswa menjadi takut/trauma, (4) tidak semua film mendidik, (5) menonjolkan percintaan, (6) meniru tokoh yang antagonis, (7) sedih, melankolis, perselingkuhan, (8) tuntutan anak seperti yang ditonton, (9) sering tidak sesuai dengan kondisi setiap hari, (10) terdapat adegan kedewasaan yang belum waktunya pada anak, 
(11) keluarga broken, berlaku kasar, (12) takut akibat buruk.

\section{Film horor/setan}

Berdasarkan analisis dari 98 pengawas sekolah menunjukkan bahwa rata-rata responden yang menyatakan bahwa film horor/ setan berdampak negatif terhadap perilaku siswa adalah $74,88 \%$ responden dan yang menyatakan berdampak positif terhadap perilaku siswa adalah $25,12 \%$. Keterangan lebih lengkap dapat dilihat pada Tabel 8 berikut.

\section{Tabel 8.}

Rata-rata, standardeviasi, minimal, dan maksimal persentase persepsi pengawas sekolah terhadap dampak film horor/ setan pada tingkah laku siswa

\begin{tabular}{lcccc}
\hline \hline Dampak & Rata-rata & Standardeviasi & minimum & maksimum \\
\hline Positif & $25,12 \%$ & 19,73 & $0 \%$ & $90 \%$ \\
Negatif & $74,88 \%$ & 19,73 & $10 \%$ & $100 \%$ \\
\hline
\end{tabular}

Berdasarkan Tabel 9 menunjukkan bahwa adanya perbedaan persepsi pengawas sekolah terhadap dampak film horor/setan yang ditayangkan televisi pada tingkah laku siswa adalah tidak terbukti $(P>0,05)$. Ini menunjukkan bahwa hipotesis nol penelitian ini diterima, yaitu tidak terdapat perbedaan persepsi pengawas terhadap dampak film horor/setan yang ditayangkan televisi pada tingkah laku siswa. Artinya bahwa sebagian besar (74,88\%) pengawas sekolah menyatakan bahwa film horor/ setan yang ditayangkan di televisi berdampak negatif terhadap tingkah laku siswa. 


\section{Tabel 9.}

Hasil Chi-Square tentang persepsi pengawas sekolah terhadap dampak film horor/setan yang ditayangkan televisi pada tingkah laku siswa

\begin{tabular}{lccc}
\hline \hline Dampak & Pearson & df & Significance \\
\hline Positif & 28,209 & 30 & 0,559 \\
Negatif & 28,209 & 30 & 0,559 \\
\hline
\end{tabular}

Contoh dampak positif siswa dalam menonton film horor/setan yang disampaikan responden di antaranya adalah: (1) anak menjadi pemberani, (2) tahu teknologi/ berseri, (3) contoh khayalan, (4) membuat hiburan, (5) meyakinkan anak ada alam gaib, (6) rasa takut menjadi biasa, (7) lebih berhati-hati, (8) tahu cerita legenda, misteri, (9) tahu sisi gelap kehidupan, (10) keimanan akhirnya menang. Contoh dampak negatif siswa dalam menonton film horor/setan yang disampaikan responden di antaranya adalah: (1) anak suka mengkhayal, (2) menimbulkan rasa takut, (3) mengganggu rokhani anak, (4) dapat meniru karakter yang keliru, (5) sering menakuti adiknya, (6) mengikuti tingkah laku pemain utama, (7) membodohi anak.

\section{Film kartun}

Berdasarkan analisis dari 98 pengawas sekolah menunjukkan bahwa rata-rata responden yang menyatakan bahwa film kartun berdampak positif terhadap perilaku siswa adalah $56,22 \%$ responden dan yang menyatakan berdampak negatif terhadap perilaku siswa adalah 43,78\%. Keterangan lebih lengkap dapat dilihat pada Tabel 10 berikut. 
Tabel 10.

Rata-rata, standardeviasi, minimal, dan maksimal persentase persepsi pengawas sekolah terhadap dampak film kartun pada tingkah laku siswa

\begin{tabular}{lcccc}
\hline \hline Dampak & Rata-rata & Standardeviasi & minimum & maksimum \\
\hline Positif & $56,22 \%$ & $21,48 \%$ & $0 \%$ & $95 \%$ \\
Negatif & $43,78 \%$ & $21,48 \%$ & $5 \%$ & $100 \%$ \\
\hline
\end{tabular}

Berdasarkan Tabel 11 menunjukkan bahwa adanya perbedaan persepsi pengawas sekolah terhadap dampak film kartun yang ditayangkan televisi pada tingkah laku siswa adalah tidak terbukti ( $P>0,05)$. Ini menunjukkan bahwa hipotesis nol penelitian ini diterima, yaitu tidak terdapat perbedaan persepsi pengawas terhadap dampak film kartun yang ditayangkan televisi pada tingkah laku siswa. Artinya bahwa sebagian besar $(56,22 \%)$ pengawas sekolah menyatakan bahwa film kartun yang ditayangkan di televisi berdampak positif terhadap tingkah laku siswa.

Tabel 11.

Hasil Chi-Square tentang persepsi pengawas sekolah terhadap dampak film kartun yang ditayangkan televisi pada tingkah laku siswa

\begin{tabular}{lccc}
\hline \hline Dampak & Pearson & df & Significance \\
\hline \hline Positif & 43,335 & 32 & 0,087 \\
Negatif & 43,335 & 32 & 0,087 \\
\hline \hline
\end{tabular}


Contoh dampak positif siswa dalam menonton film kartun yang disampaikan responden di antaranya adalah: (1) anak terhibur dan senang, (2) banyak sikap yang positif untuk ditiru, (3) tepat untuk pelajaran anak, (4) lucu, banyak akal sesuai jiwa anak, (5) membangkitkan fantasi anak, (6) perkembangan teknologi, (7) berlaku pahlawan, (8) mendidik sopan santun, (9) anak dapat belajar membaca, (10) banyak menampilkan tokoh yang jujur. Contoh dampak negatif siswa dalam menonton film kartun yang disampaikan responden di antaranya adalah: (1) banyak waktu tersita, (2) terlalu mengkhayal, (3) mudah meniru sikap negatif, (4) anak berkeinginan mencoba/meniru, (5) sering tidak sesuai dengan aturan keluarga atau budaya timur.

\section{Film keagamaan}

Berdasarkan analisis dari 98 pengawas sekolah menunjukkan bahwa rata-rata responden yang menyatakan bahwa film kartun berdampak positif terhadap perilaku siswa adalah $86,73 \%$ responden dan yang menyatakan berdampak negatif terhadap perilaku siswa adalah $13,27 \%$. Keterangan lebih lengkap dapat dilihat pada Tabel 12 berikut.

\section{Tabel 12.}

Rata-rata, standardeviasi, minimal, dan maksimal persentase persepsi pengawas sekolah terhadap dampak film keagamaan pada tingkah laku siswa

\begin{tabular}{lcccc}
\hline \hline Dampak & Rata-rata & Standardeviasi & minimum & maksimum \\
\hline Positif & $86,73 \%$ & $16,55 \%$ & $10 \%$ & $100 \%$ \\
Negatif & $13,27 \%$ & $16,55 \%$ & $0 \%$ & $90 \%$
\end{tabular}


Berdasarkan Tabel 13 menunjukkan bahwa adanya perbedaan persepsi pengawas sekolah terhadap dampak film keagamaan yang ditayangkan televisi pada tingkah laku siswa adalah tidak terbukti ( $P>0,05)$. Ini menunjukkan bahwa hipotesis nol penelitian ini diterima, yaitu tidak terdapat perbedaan persepsi pengawas terhadap dampak film keagamaan yang ditayangkan televisi pada tingkah laku siswa. Artinya bahwa sebagian besar $(86,73 \%)$ pengawas sekolah menyatakan bahwa film keagamaan yang ditayangkan di televisi berdampak positif terhadap tingkah laku siswa.

Tabel 13.

Hasil Chi-Square tentang persepsi pengawas sekolah terhadap dampak film keagamaan yang ditayangkan televisi pada tingkah laku siswa

\begin{tabular}{llll}
\hline \hline Dampak & Pearson & df & Significance \\
\hline Positif & 43,335 & 32 & 0,087 \\
Negatif & 43,335 & 32 & 0,087 \\
\hline \hline
\end{tabular}

Contoh dampak positif siswa dalam menonton film keagamaan yang disampaikan responden di antaranya adalah: (1) mencontoh tindakan yang positif, (2) menanamkan aqidah atau budi pekerti, (3) meningkatkan ketaqwaan, (4) selalu ingat kepada Tuhan, (5) memberi tuntunan hidup, (6) menambah keimanan, (7) mendidik anak tekun berdoa, (8) anak hormat kepada orangtua dan guru, (9) mudah melaksanakan agama. Contoh dampak negatif siswa dalam menonton film keagamaan yang disampaikan responden di antaranya adalah: (1) meniru 
perbuatan yang negatif, (2) ada unsur dibuat-buat, (3) mengubah keyakinan anak, (4) terdapat penyampaian yang kurang sesuai, (5) pelakunya tidak sesuai dengan kenyataan.

\section{KESIMPULAN DAN SARAN}

Berdasarkan semua uraian di atas, maka hasilnya dapat disimpulkan dengan adanya temuan-temuan dan saran seperti berikut ini. Berdasarkan analisis Chi-Square dari 98 responden pengawas sekolah dari 15 propinsi, maka diperoleh tujuh hasil penelitian seperti berikut ini. Hasil penelitian yang pertama menunjukkan bahwa menonton televisi dalam hari-hari sekolah mengganggu belajar siswa. Alasannya di antaranya adalah karena: (1) dapat lupa belajar jika acaranya menarik, (2) konsentrasi belajar siswa tidak terfokus, (3) acaranya tidak sesuai dengan mata pelajaran, (4) siswa menjadi malas belajar, (5) waktunya tidak teratur, (6) belum semua siswa menyadari, (7) siswa mudah terpengaruh dengan tokoh tertentu.

Hasil penelitian yang kedua menunjukkan bahwa iklan yang ditayangkan di televisi dapat berdampak negatif terhadap perilaku siswa. Contohnya di antaranya adalah: (1) siswa ingin mencoba, (2) meniru gerakan yang diperagakan, (3) ingin memiliki semua yang diiklankan, (4) mencontoh yang tidak baik, (5) tidak semua produk sesuai dengan kondisi siswa.

Hasil penelitian yang ketiga menunjukkan bahwa film komedi berdampak positif terhadap perilaku siswa. Contohnya di antaranya adalah: (1) dapat menghibur, (2) belajar humor, (3) menambah wawasan, (4) memahami isi cerita, (5) mengurangi stres/refresing, (6) meniru perilaku yang baik.

Hasil penelitian yang keempat menunjukkan bahwa film drama keluarga berdampak positif terhadap perilaku siswa. Contohnya di antaranya adalah: (1) menghargai orangtua, (2) memanfaatkan pesan baik, (3)menenal keluarga, (4) lebih mengenal kehidupan, (5) menyelesaikan masalah keluarga, (6) simpatik pada tokoh, (7) mencari idola, (8) kasih sayang, (9) membina sikap, (10) belajar memecahkan masalah. 
Hasil penelitian yang kelima menunjukkan bahwa film horor/setan yang ditayangkan di televisi dapat berdampak negatif terhadap perilaku siswa. Contohnya di antaranya adalah: (1) anak suka mengkhayal, (2) menimbulkan rasa takut, (3) mengganggu rokhani anak, (4) dapat meniru karakter yang keliru, (5) sering menakuti adiknya, (6) mengikuti tingkah laku pemain utama, (7) membodohi anak.

Hasil penelitian yang keenam menunjukkan bahwa film kartun berdampak positif terhadap perilaku siswa. Contohnya di antaranya adalah: (1) anak terhibur dan senang, (2) banyak sikap yang positif untuk ditiru, (3) tepat untuk pelajaran anak, (4) lucu, banyak akal sesuai jiwa anak, (5) membangkitkan fantasi anak, (6) perkembangan teknologi, (7) berlaku pahlawan, (8) mendidik sopan santun, (9) anak dapat belajar membaca, (10) banyak menampilkan tokoh yang jujur.

Hasil penelitian yang ketujuh menunjukkan bahwa film keagamaan berdampak positif terhadap perilaku siswa. Contohnya di antaranya adalah: (1) mencontoh tindakan yang positif, (2) menanamkan aqidah atau budi pekerti, (3) meningkatkan ketaqwaan, (4) selalu ingat kepada Tuhan, (5) memberi tuntunan hidup, (6) menambah keimanan, (7) mendidik anak tekun berdoa, (8) anak hormat kepada orangtua dan guru, (9) mudah melaksanakan agama.

Berdasarkan ketujuh hasil penelitian di atas, maka sebagai penutup penelitian ini disarankan agar para orangtua murid, guru, siswa, dan pengelola pendidikan perlu memberi pengarahan/saran secara konkret kepada anak/siswanya pada saat menonton televisi terutama pada hari-hari sekolah khususnya pada saat menonton iklan dan film horor/setan. Khususnya kepada orangtua murid atau 
keluarga di rumah agar mendampingi dan memberikan penjelasan yang logis dan positif kepada anaknya pada saat menonton film yang ditayangkan di televisi, khususnya menonton iklan dan film horor/setan.

\section{DAFTAR PUSTAKA}

Aronson, Elliot, Wilson Teinthy D, and Akert, Robin M. (1994). Social Psychology: The Heart and the Mind. New York: Harper Collins College Publishers.

Baihaqi, Mif (Penyunting) (1998). Anak Indonesia Teraniaya. Bandung: PT Remaja Rosdakarya.

Bell-Gredler, Margaret E. (1986). Learning and Instruction: Theory into

Practice. New York: Macmilan Publishing Company.

Cronbach, Lee J. (1963). Educational Psychology. New York: Harcourt, Brace \& World, Inc.

Munandar, S.C. Utami. (1990). Mengembangkan Bakat dan Kreativitas Anak Sekolah: Petunjuk Bagi Para Guru dan Orang Tua. Jakarta: PT Gramedia.

Myers, David G. (1993). Social Psychology. New York: McGraw-Hill, Inc.

Myers, David G. (1994). Exploring Social Psychology. New York: McGraw-Hill, Inc.

Raven, Bertram H. and Rubin, Jeffrey Z. (1983). Social Psychology. New York: John Wiley \& Sons, Inc.

Sutherland, Peter. (1992). Cognitive Development Today: Piaget and his Critics. London: Paul Chapman Publishing Ltd. 